\title{
Role of circulating tumor cells in future diagnosis and therapy of cancer
}

\author{
Pravin D. Potdar, Navjeet Kaur Lotey \\ Department of Molecular Medicine and Biology, Jaslok Hospital and Research Centre, Mumbai 400026, Maharashtra, India.
}

Correspondence to: Dr. Pravin D. Potdar, Department of Molecular Medicine and Biology, Jaslok Hospital and Research Centre, 15 Dr. G. Deshmukh Marg, Mumbai 400026, Maharashtra, India. E-mail: ppotdar@jaslokhospital.net

\section{A B S T R A C T}

Circulating tumor cells (CTCs) have become a blistering topic of discussion for oncologists because of their tremendous potential in the diagnosis and treatment of cancer. Over the past few years, they have been doled with quite an amount of research in this area understanding that CTCs are shed from tumors and circulate in the bloodstream. This process can also occur at an early stage of cancer. The major limitation in isolation of CTCs is their availability in limited numbers. Hence, many techniques have been developed and are under continuous improvement to enhance their efficacy of CTC isolation and enumeration. They have shown their potentiality to not just indicate the presence of a tumor but also to provide us with its core information. They have also proven to be useful in detecting minor subgroups of cells present in the primary tissue which might eventually be the cause of treatment resistance or relapse of the disease. Hence, detecting and characterizing CTCs can definitely become an inevitable step in treating solid tumor malignancies. In this review, we have tried to comprehend the basics of CTCs including isolation, detection, characterization, and molecular mechanism of their circulation in the blood stream. We have mostly focused on the significance of CTCs in diagnosis and therapies of four most common types of cancers, namely, breast, prostate, lung, and colorectal. This review provides the coverage of most of the advancements with regards to different tumor malignancies and their probable use in predicting outcomes of the disease to realize the concept of personalized medicine.

Key words: Cancer stem cells, circulating tumor cells, epithelial to mesenchymal transition, metastasis, molecular markers, personalized medicine

\section{Introduction}

Cancer is a collective term for uncontrolled malignant tumor growth taking place in any tissue of the body. More than 100 types of cancers are known till date, some of them being more common in specific genders such as in case of women; breast cancer is of the most common whereas in men, prostate cancer is quite common. ${ }^{[1]}$ Other types of cancer like lung, colon, blood, lymph are found in both men and women. Surgery, radiotherapy, chemotherapy are the established treatments for cancer which also constitute significant side effects. However, there is still a long way to go to constitute $100 \%$ efficacious results because of heterogeneity and resistant of tumor cells to available therapies of cancer. ${ }^{[2]}$ Each of the subtypes responds differently to the treatment and makes it difficult to attain a replete cytogenic response. Cancers are also known for attaining complex diversity which makes it difficult for clinicians to choose the treatment procedure. ${ }^{[3]}$ Some prevalent mutations or the ones attained during the course of treatment may also result resistance to the therapy. In such cases,

\begin{tabular}{|l|l|}
\hline \multicolumn{2}{|c|}{ Access this article online } \\
\hline Quick Response Code: & Website: \\
\hline & www.jcmtjournal.com \\
\cline { 2 - 2 } & \\
\hline
\end{tabular}

continuation of the same treatment only worsens the condition, therefore, there is a need of extremely specific and targeted therapy which can help the survival of patients in such situations. ${ }^{[4]}$ It is increasingly becoming a prerequisite to take a "fingerprint" of a given tumor and then proceed with a "tailor-made" treatment. Circulating tumor cells (CTCs) can provide us with the required information and pave a new avenue in future cancer therapies.

\section{Mechanism of Cancer Development}

Most cancer remains asymptomatic at early stages and start showing up signs only in later stages of development. It is difficult to treat the patient in advanced stages of cancer, because the tumor spreads itself in various tissues of the body which is referred as invasion and metastasis of cancer. ${ }^{[5]}$ The actual trigger which initiates this process remains obscure. However, CTC-based technologies may predict the pathway of metastasis. A malignant tumor cell has many cell cycle pathways abnormally regulated. Initially, the epithelial cells of a primary tumor infest nearby blood or lymphatic vessels and circulate in them as shown in Figure 1. Of the many altered pathways in these cells, one of them is the production of a protein called matrix metalloproteinase (MMP). ${ }^{[6]}$ Upon metastasis of a tumor cell, it breaks from the main tumor and enters the extracellular space which is mainly made up of collagenous fibers. The tumor cells secrete MMP, which breaks collagen fibers as well as the basement membrane surrounding the blood and lymph vessels. 
The tumor cells now gain direct access to the epithelial membrane of the vessels and squeeze into them through the tight junctions. ${ }^{[7]}$ Once into the bloodstream, they can easily transport to other tissues of the body and invade them. An aggressive tumor cell can attach itself to the endothelial membrane of the vessel and create a "pore" through which it escapes out and invade the nearby tissue. ${ }^{[8]}$ Other less aggressive tumor cells can use this pore to enter the same tissue and establish a new tumor. Malignant tumors also initiate angiogenesis to enhance blood supply around the tumor and support its growth and development. ${ }^{[9]}$ All this time, when several changes are taking place during the course of tumor growth, an important phenomenon is the shedding of cells from the primary tumor in the bloodstream as CTCs. ${ }^{[10]}$ These cells carry tremendous information about the presence of tumor, its growth stage and mutations that it harbors. Due to this vital data, they have enormous applications in the detection, staging and treatment guidance of solid tumor malignancies. In this review, we have discussed about their significance, isolation, enrichment techniques and the advancements in the field of molecular biology of CTCs in major types of cancers including breast, prostate, colorectal, and lung cancer.

\section{Circulating Tumor Cells}

CTCs are described as cells shed by a primary tumor into vasculature and they keep circulating in the blood stream of cancer patients. ${ }^{[10]}$ Scientists have tried to decipher their nature and significance. CTCs are known to be circulating in the body fluids before they metastasize to various parts of the body even in primary stages of the disease. ${ }^{[10]}$ However, they are not easily identified, as they are present in a very small numbers. It is estimated that a teaspoon of blood might contain just about 5-50 CTCs. CTCs first exuviate from the primary tumor and remain in the blood stream for a while till the time it wedges itself in a new tissue as shown in Figure 1. Some CTCs can adhere to the wall of capillaries and bunk to enter a new tissue. While in the blood stream, they might

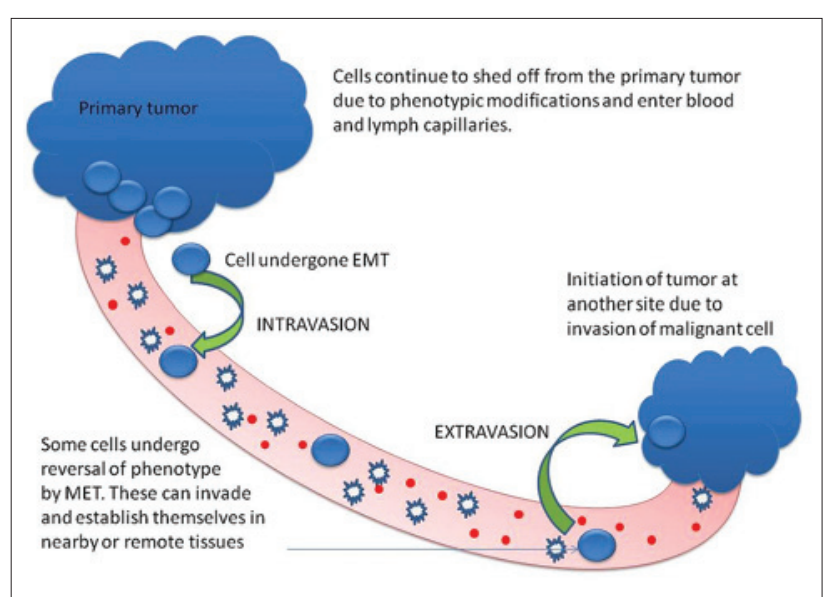

Figure 1: Cells migrating from primary tumor into blood stream and to a site of invading another tissue even clog capillaries due to their big size. ${ }^{[11]}$ Many CTCs can be shed from a given tumor in different locations. A given tumor may vary in nature at different locations, that is, it may display heterogeneity. CTCs released from different locations of a tumor may exhibit discrepancies of a given tumor. Thus, CTCs can contribute to a potpourri of heterogeneous cells disgorged from the same tumor. $^{[11]}$

Despite consistent efforts, researchers are yet to gather its caboodle. Of the known properties, one of them is that they undergo epithelial to mesenchymal transition (EMT) as shown in Figure 2. This results in change with respect to epithelial markers and other cellular properties. ${ }^{[12]}$ An epithelial cell starts behaving like a mesenchymal cell and can detach itself from the parent tissue and become a free flowing entity. CTCs use this property to invade blood and lymph capillaries and swim freely in them. Not all CTCs undergo complete EMT; some of them undergo just partial changes or partial EMT. CTCs undergone complete EMT can revert their phenotype by undergoing mesenchymal to epithelial transition (MET) out of which some can contribute to micro or macro-metastasis leading to cancer progression. ${ }^{[13]}$ When a tumor cell undergoes reversion by MET, they regain properties of cell adhesion. These cells first adhere to the wall of capillaries and then evade from them to nearby tissues. Since they can now behave as epithelial cells again; they adhere to the target site and start dividing and re-dividing giving rise to a new tumor. However, EMT transition can also lead to a perplexed situation as there is a lot of diversity in the morphological transformations.

\section{Significance of CTCs}

One of the most axiomatic implications of CTCs is that they are minimally invasive indicators. ${ }^{[12,13]}$ Detection of CTCs can reveal mint of information rather than just the presence of a tumor. They can help us to realize the concept of tailor-made medicine. Analysis of CTCs

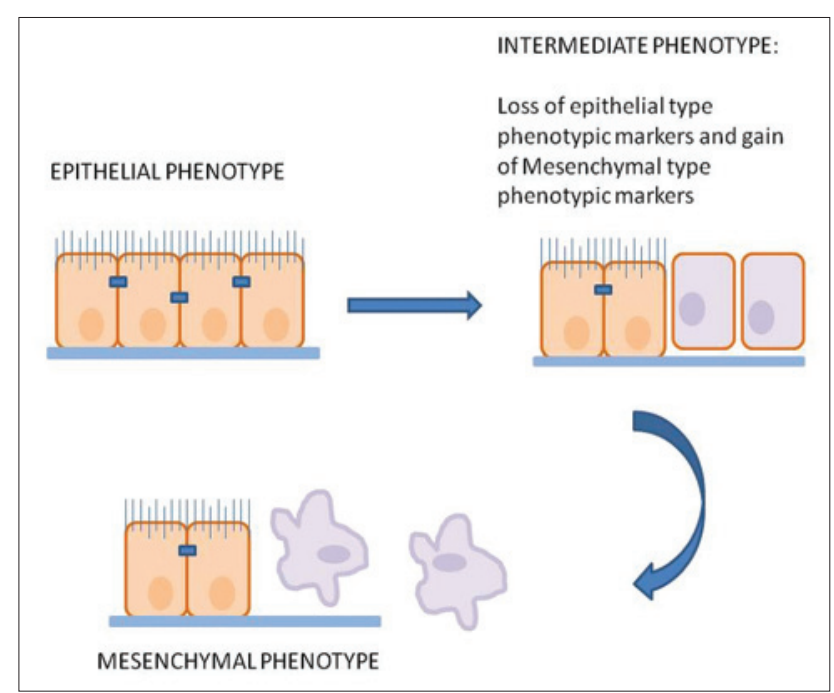

Figure 2: Transition of cells from epithelial to mesenchymal phenotype 
can save a patient from worsening the condition with unsuitable medications. Furthermore, the earlier they are detected, faster and better treatment options can be made available to the patient. It provides the basis of understanding mutations and genotypic changes of malignant cells and hence provides the best suitable targeted therapy. CTCs are multifunctional biomarkers and enable us to assess the patient serially along the treatment journey. They are potentially an alternative to invasive biopsies for detection, characterization and monitoring of non-hematological cancers. ${ }^{[14]}$ Although as of now it is not clear whether CTCs are the cause of metastasis, they still hold the potential for being a cause for disease progression. Metastasis is better known to be caused by cancer stem cells (CSCs), which are highly motile, self-renewing cancer initiators. They also have increased resistance to apoptosis as well as to certain treatment drugs. CTCs with such properties can be metastatic in nature. CTCs after undergoing EMT can also make non-CSC type cells to behave like CSCs. In addition, it is yet to be clarified whether cells with metastatic potential have increased motility and aggressive nature of CTCs as compared to non-metastatic tumor cells. On the whole, CTCs give us biological insights of the disease condition, progression, and treatment prediction. Reports indicate that patients with fewer numbers of CTCs survive longer than the patients which have more number of CTCs. ${ }^{[15]}$ Another important implication of CTCs is that they can form the constitutional basis of tumor staging. ${ }^{[16]}$ The types and quantity of CTCs can form prima facie of the degree and type of cancer. They can be periodically used to keep a check on disease progression. In some cases, they have even been able to identify the drug targets by analyzing the enumerated CTCs and its phenotype. They can even help in the selection of secondary treatment options while the patient has failed to respond to first line treatments. ${ }^{[17]}$ One such example is the detection of human epidermal growth factor receptor 2 (HER2)-positive CTCs in HER2-negative breast cancers. ${ }^{[18]}$ Thus, it gives us hints and specks about quiescent population that may be present in the tumor and be the cause of drug resistance or relapse of the disease. ${ }^{[19]}$ Since, CTCs hold such critical information about a tumor and its characteristics; they can definitely form the pedestal of patient-specific treatments. The great enigma about cancer can adjudicate with the help of information retrieved from CTCs analysis.

\section{Isolation and Analysis of CTCs}

In the recent years, CTCs have gained increasing importance because of their multi potential uses. Despite their long known discovery and spates in clinical oncology, no method has been devised to isolate or enumerate CTCs efficiently. Primarily, their quantity in blood circulation is the biggest hurdle in isolation of CTCs. Out of the several CTCs shed by the primary tumor only about $0.1 \%$ survives in the circulation and only about $0.01 \%$ is responsible for metastasis. ${ }^{[17]}$ It has been reported that CTCs are not continuously shed in the circulation. They are discontinuous and might not be present in homogenous condition. Thus, while isolating CTCs a single blood sample might fall insufficient or may give inaccurate results. ${ }^{[20]}$ This is accompanied by further reduction in their numbers when they get clogged in capillaries due to their large size. They can also form clusters while flowing and some of them may even adhere to the walls of the capillaries, or some might be cloaked by the platelets. Further reduction in CTCs number takes place during batch processes which are followed for their enrichment. Simpler methods involve size based separation, collagen adhesion method or density-based separation. Other sophisticated ones rely on epithelial markers, immunomagnetic techniques, microchips, and nanotech approaches. ${ }^{[21]}$

\section{Density-based Ficoll-Hypaque method}

Gertler et al. ${ }^{[22]} 2003$ have used Ficoll-Hypaque density-based separation method to separate tumor cells from bone marrow and peripheral blood aspirations. It is based on differential migration of cells which takes places during centrifugation and gives a layered separation of cells types. The porous barrier is permeable to the red blood cells and other smaller components of blood. The buffy coat above this layer is of concern, as it contains the tumor cells along with leukocytes. This layer can be easily aspirated and analyzed further to determine the presence and quantification of CTCs. ${ }^{[21]}$

\section{Immunomagnetic (antibody based) method}

This method exploits the presence of surface markers on tumor cells or hematopoietic cells. In this method, antibodies are coupled with magnetic particles and then used for positive or negative selection of CTCs. In positive selection, surface markers of CTCs are targeted, whereas, in negative selection, depletion of blood cells other than CTCs is achieved by targeting their surface markers $^{[23]}$ as shown in Figure 3. Epithelial cell adhesion molecule (EpCAM) is one of the most widely tapped markers on tumor cells. CD45 in case of lymphocytes and glycophorin for erythrocytes are two commonly used markers in case of negative selection. MACS ${ }^{\circledR}$ has introduced microbeads which can be used in such negative selection. ${ }^{[24]}$

Food and Drug Administration (FDA) has approved CellSearch $^{\circledR}$ (by Janssen Diagnostics) which is by far the most efficacious system for extraction and enumeration of CTCs. ${ }^{[25]}$ The CTCs according to this system are defined by a characteristic round oval shape cells with nucleus which is stained by 4',6-diamidino-2-phenylindole stain. This procedure may be laborious and intensive but gives the best enrichment results as a comparison to other existing techniques. It makes use of antibodies like EpCAM attached to magnetic beads for binding to specific tumor cell surface receptors. These cells can be pulled out from the rest of cells under the influence of a magnetic field. ${ }^{[26]}$ Some tumor cells might escape the 


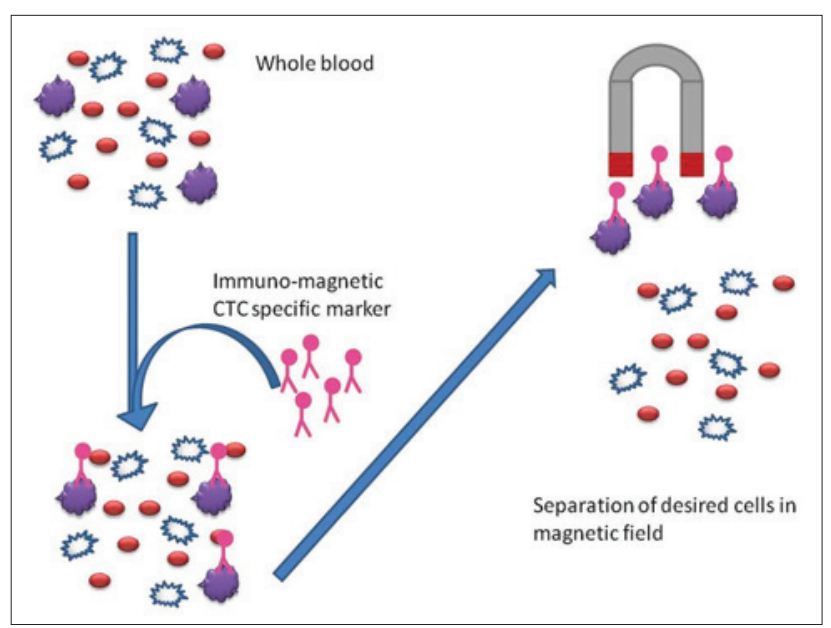

Figure 3: Immunomagnetic separation of circulating tumor cells

antibodies as they undergo EMT transitions while some other tumor cells belonging to a smaller sub-population might also be ignored. Some CTCs remain undetected throughout this process. ${ }^{[27]}$ Hence, although this method is being used currently for experimental purposes, there is yet lot of scope for improvisation in the quantitative as well as qualitative aspects of tumor cell detection.

\section{Microfluidics method}

As antibody-dependent cell sorting is not a completely reliable source. There are a lot of hurdles in accomplishing higher percent enrichment of cells from the whole blood. Hence, it is important to take into consideration other methods which rely on antibody-free systems. In this method, cell size-based sorting is accomplished using microfluidic technology. ${ }^{[28]}$ The microfluidic chamber is made up of special materials and is usually spiral or curvilinear. When whole blood is allowed to pass through this micro-chamber, inertial lift forces and drag forces help in sorting of the cells. These forces rely on differential sizes of cell in the sample. In case of CTCs, whole blood or leukocyte along with CTCs fraction can be used as a feed in input. As they pass through the microfluidic chamber, the forces will act on the cells and start separating them based on size. The CTCs incline more towards the inner wall (larger size) while other cells such as white blood cells and red blood cells will incline towards the outer side of the wall (smaller size). ${ }^{[29]}$ They can be collected in separate fragments at the end of the tube, where it bifurcates into collecting chambers as shown in Figure 4. Recent advances have allowed the procedure to be carried out with minimal loss of cell types. ${ }^{[30,31]}$

\section{Size based separation method}

As CTCs are usually bigger in size compared to other components, this characteristic is put to use. This method can even be used to detect the presence of a single tumor cell in a quantity of blood as little as $1 \mathrm{~mL}$ (shown in Figure 5). ISET $^{\circledR}$ is one such established method which

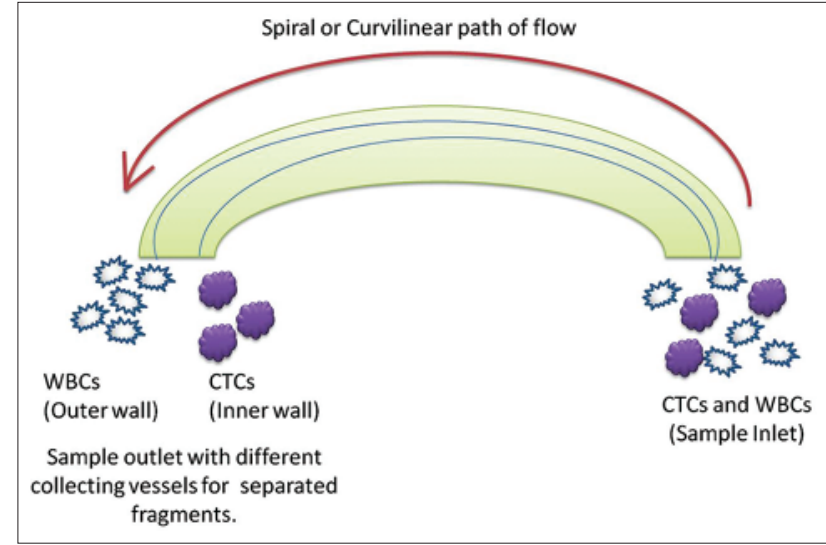

Figure 4: Microfluidic-based separation of circulating tumor cells

is used for such type of cell size based sorting. Specially designed filter are employed to allow blood components to percolate through them. CTCs being bigger in size will not be able to pass through the membrane and hence remain over it. They can be then collected from over the membrane filter and subjected to analysis. ${ }^{[32]}$

\section{Other techniques}

The FDA approved cell detection method has quite some limitations. Hence, a lot of attempts are being made to invent better techniques which are highly efficient low on cost, less labor intensive, and time savers too. Metacell ${ }^{\circledR}$ is another cell size-based sorting method which has been introduced lately. ${ }^{[32,33]}$ Microchips and micro slides are being designed to exploit various differential properties of cells. Lu et al. ${ }^{[34]}$ have introduced a device which they refer to as Nan Velcro CTCs Chip. They claim that this device is much more efficient and reproducible as compared to CellSearch $^{\circledR}$ kit. This kit is composed of a patterned silicon nanowire substrate which is overlaid with polydimethylsiloxane mixture. ${ }^{[34]}$ While another cell surface marker-based systems is a flow cytometry fluorescenceactivated cell sorting. ${ }^{[35]}$ Another emerging technique is making use of dielectric constants of cells such as the DEPArray system. ${ }^{[26]} \mathrm{Ju}$ et al. ${ }^{[36]}$ have described a method where they make use telomerase activity to isolate melanoma cells in peripheral blood. As telomerase activity is elevated in cancerous cells rather than normal cells, they made use of an adenoviral vector human telomerase reverse transcriptase to drive the expression of green fluorescent protein which can be used to isolate CTCs in this method. An interesting device called VeriFAST is an integrated system which can isolate cells as well as perform down streaming processes including staining with EpCAM and other antibodies to isolate CTCs. ${ }^{[37]}$ Many more such technological advancements have been reported by scientists all over the world. There are several newer assays are being introduced which are focused on marker free isolation such as chromatography, filtration, and dielectrophoresis for capturing CTCs from cancer patients. $^{[38]}$ Few of them have been mentioned under specific cancer categories discussed ahead in this review. 


\section{Characterization and Molecular Profiling of CTCs}

We have discussed various CTCs enrichment techniques which are being used for isolation of CTCs from metastatic cancer patients. However, none of them has achieved much of quantitative success. The results have shown a great amount of variation from $10 \%$ to $90 \%$ of isolated CTCs and hence, it is crucial to analyze the collected cells for their quantity as well as their exact phenotype. A numerical indication of collected CTCs may not be able to reveal the true picture of the type of cells isolated from cancer patients. Similarly, tumor cells can undergo a variety of changes and be present in heterogeneous subpopulations. Hence, a mere number of CTCs can lead to faulty conclusions. Therefore, there is a need for true characterization of these isolated CTCs cells to come to logical conclusions. Molecular profiling of these isolated cells will crystallize the picture, as it reveals the true nature of the isolated CTCs cells.

A fundamental process in EMT, down-regulates E-cadherin, which can be attained by many transcriptional factors. ${ }^{\left[{ }^{[3]}\right.}$ Most of the molecular markers that have been isolated for characterizing CTCs are EMT indicators. During EMT process, a metastatic cell goes through a lot of modifications at cellular and molecular levels and many genes undergo transcriptional alterations. ${ }^{[39]}$ Some of these genes play a role in initiating the effect of EMT while others play a role in regulating and maintaining its transited state. The other factors like inflammatory cytokines and physical changes in the tumor microenvironment also play a role in EMT promotion. ${ }^{[39]}$ TWIST1 and TWIST2 genes are most strongly expressed genes in EMT process which are responsible for inducing transformation alone or in co-operation with other factors such as TGF $\beta$, Wnt, Notch, etc. ${ }^{[40]}$ E-cadherin is one of the most important proteins for maintaining the epithelial nature of cells. Snail1 and Snail2 suppress the transcription of E-cadherin as well as Zeb1 and Zeb2 genes. This results into downregulation of E-cadherin, which leads to initiation of EMT process. ${ }^{[41,42]}$ Other gate keeper's genes of epithelial state, such as alpha and gamma catenins are also been down-regulated along with downregulation of E-cadherin in this process. ${ }^{[43,44]}$

Induction of certain mesenchymal characters during EMT process requires upregulation of two extracellular matrix proteins, that is, vimentin and fibronectin in these cells which escape the barriers of local tissue and proceeded for invasion. Similarly, other genes such as N-cadherin, CD44, intergrin $\beta 6$ are also implicated for proper migration of these cells. ${ }^{[43-46]}$ Even understanding the mutational changes, abnormal size, and characteristics of CTCs, scientists are still pondering over the fact that these cells are able to survive in an environment which is totally hostile for them. It is postulated that out of the several hundred CTCs shed by the tumor, only a few remain in the circulation. There are reports suggesting that CTCs bearing mutations, such as upregulation of CD47, help them in escaping attack by natural killer cells and macrophages. Similarly, downregulation of chaperone protein-calreticulin again helps them to dodge the immune system. ${ }^{[47,48]}$ Schölch et al. ${ }^{[49]}$ in their studies have referred this state as an "immune-evasive" to the period between EMT and MET in circulation. Thus, overall it seems that CTCs have very evolved mechanisms to maintain and express their invasive aggressive nature by surpassing the body's natural immune system.

\section{CTCs in Breast Cancer Diagnosis and Treatment}

Breast cancer is one of the most common types of cancer detected in women. Last two decades, due to early diagnosis and advancement in treatment protocols, breast cancer mortality has been considerably reduced. However, there is no hope of survival when patient condition progresses to the metastatic stage. Recent studies have shown that CTCs which are shed from tumor are mediator of metastatic dissemination and form micrometastasis at distant organs. ${ }^{[50]}$ Due to advancement in technology, several methods have been established to isolate CTCs from metastatic breast cancer patients. CTCs derived from breast cancer patients are among the most extensively studied for diagnosis and treatment of breast cancer. ${ }^{[50]}$ There is a direct co-relation of CTCs with disease prognosis and survival has been reported in many cases. It has been shown that if there is more number of CTCs, there are less chances of survival. ${ }^{[50]}$ The progression of the disease and its response to treatment can be very well-monitored by characterizing CTCs which are disseminated from the primary tumor. It has shown that the presence of CTCs, despite of ongoing treatment, is an indicative of worse overall survival. ${ }^{[51]}$ Hence, it is very important to characterize CTCs for better understanding of this disease progression and cure. ${ }^{[51]}$

Due to large size and few numbers of CTCs in blood circulation of metastatic breast cancer patients, the isolation and enumeration of captured CTCs have proven to be of prognostic value in breast cancer evaluation and treatment. One of technologies presently in use is the CellSearch $^{\circledR}$ system, which works on a principle of selecting CTCs as per the positive expression for EpCAM and cytokeratin (CK) protein on the surface of these cells..$^{[2]}$ Although it has proven greatly useful and reproductive, it may limit the selection due to EMT transition process. CTCs which have undergone EMT will show downregulation of epithelial markers including EpCAM. ${ }^{[52]}$ In some cases, it has been observed that HER2-positive metastatic breast cancer shows the presence of EpCAM negative CTCs. ${ }^{[53]}$ Hence, EpCAM independent methods could fetch an increase in number of capture of CTCs. Second, detecting CTCs on the 
basis of HER2 expression has been suggested in many cases. CTCs vary in expression and frequency of this gene, and it can be directly correlated with the disease's progression and survival. ${ }^{[54]}$ Not only about correlating the primary tumor's characteristics, CTCs can reveal more vital information, which is at times not detected by mere analysis of primary tumor. In a particular group of HER2- breast cancer patients, HER2+ CTCs are identified. ${ }^{[55]}$ This leads to consideration of revision in the ongoing treatment of the disease. Trastuzumab-based therapy is applied to these patients with HER2+ CTCs and HER2- primary tumor. This study has shown that 1 out of 4 patients are treated completely while 2 patients have attained partial response to this treatment. Even though this study number of patients are few, it has given important facts about CTCs. It has helped in identifying the changing course of the disease well before time. Thus, CTCs hold the potential to represent the metastatic state of HER2- breast cancer. ${ }^{[55]}$

CTCs have been reported to harbor many types of mutations and transformations. Obermayr et al. ${ }^{[56]}$ have shown that genes like EpCAM and secretoglobin, family 2A and SCGB2A2, can be used as important markers in the detection of CTCs in breast cancer. CTCs have been reported to establish mutations after dissemination from the primary tumor and some of these mutations may help the circulating cells to attain enhanced survival and therefore molecular profiling of CTCs holds the importance in understanding the real state of disease. Monitoring the CTCs with respect to CK19 expression can reveal the nature of metastatic potential of the tumor. CK19 expression in CTCs has been prognostic for worse overall outcome of the disease. CK19 as well as TP53 mutations are mostly found in all of the CTCs derived from triple negative breast cancer patients. ${ }^{[57]}$ Some researchers believe that it can be one of the driving factors to the progression of the disease to triple negative stage. ${ }^{[53]}$ It has also been shown that breast cancer patients which expressed KRT19, SCGB2A2, and ERBB2 genes showed poor survival rates. ${ }^{[56]}$ IGF-IR mutation has also been observed to be expressed in patients of breast cancer at a metastatic stage of disease. Furthermore, mutations in $P I K 3 C A$ gene and ERBB2 mutations are reported in CTCs of some patients whose primary tumor did not share this state of disease. ${ }^{[57,58]}$ Apart from these mutations, EMT changes have been one of the critical properties of CTCs. Most of the CTCs isolated from breast cancer patients show the presence of EMT markers such as ETV5, NOTCH1, SNAIL, TGFB1, ZEB1, and ZEB2. ${ }^{[41]}$ The mutational and transitional changes taking place in CTCs make them gain an aggressive behavior which in turn helps them to break apart from the basement membrane and disseminate from the tumor. ${ }^{[59]}$ EMT pathway and PIK3CA mutations have been related to progression of the disease to metastasis in many cases. ${ }^{[60,61]}$ Hence, molecular profiling of CTCs is becoming increasingly important both to understand the state of the disease and then select an optimal treatment for a given patient. ${ }^{[62]}$ It has been reported that the presence of genes like EpCAM, CCNE2, DKFZp762E1312, EMP2, MAL2, PPIC, or SLC6A8 can be related with the presence of CTCs in peripheral blood. ${ }^{[56,62]}$

In breast cancer, chemotherapy is one of the standard modes of treatment. During the course of this therapy, CTCs values are determined before and after rounds of chemotherapy. In most of the cases with non-metastatic state of breast cancer, reduction in number of CTCs is observed after the first round of chemotherapy. However, it was also noted that CTCs had a tendency to attain resistance to the therapy. Hence, it is suggested that a regimen of increasing doses should be deployed in the progressing rounds of chemotherapy. ${ }^{[63]}$ Studies by Peeters et al. ${ }^{[64]}$ have revealed some statistics about CTCs count and disease state. In a small group under their study, about $80 \%$ of patients who had more than 80 CTCs in $7.5 \mathrm{~mL}$ of blood died within one year from diagnosis of metastasis of disease. In a similar study by Smerage et al., ${ }^{[65]}$ it has been observed that CTCs continued to remain detected after first round of chemotherapy in some patients of breast cancer. It is observed that such patients are in rapid progression of the disease to metastasis. They have further suggested that in such cases, it can be ideal to opt for some alternative treatment with some of the novel therapeutic agents rather than continuing with the same chemotherapy. ${ }^{[6]}$

\section{CTCs in Prostate Cancer Diagnosis and Treatment}

Prostate cancer originates in the prostate gland of male reproductive system. Fusion of TMPRSS2 and ERG genes is identified as one of prime reasons leading to prostate cancer which is often accompanied by loss of PTEN. ${ }^{[67]}$ Biopsy remains the test for full confirmation of this disease. Less invasive processes are sometimes conducted to detect this disease as well as to understand its progression. Prostate-specific antigen (PSA) level detection is one of such tests which can be used to identify the presence of disease and monitor the treatment effect in these patients. However, PSA levels may not be always necessarily indicative of the disease progression as PSA level may raise due to reasons other than prostate cancer. Similarly, fall in levels of PSA during treatment may not be necessarily indicative for the eradication of the prostate tumor. It has been shown that drugs targeting androgen receptor (AR) may bring down levels of PSA but not necessarily cure the disease simultaneously. Hence, a better prognostic marker is greatly demanded. When PSA testing falls insufficient to validate the course of treatment, CTCs isolation enumeration and characterization can act as a reliable marker for diagnosis and therapy of prostate cancer. ${ }^{[68,69]}$

In a study by Attard et al. ${ }^{[70]}$ have captured circulating, non-apoptotic nucleated, EpCAM+ CK+ CD45- cells 
from prostate cancer patient's blood and confirmed for their malignant origin and hormone-regulated expression of ERG1. Thus, CTCs hold great potential to identify and stage the prostate cancer with minimal invasive procedures. ${ }^{[70]}$ Giesing et al. ${ }^{[71]}$ have identified overexpression of five genes, namely, SOD2, GPX1, $A R$, cyclin $B$, and $b F G F$ which have predicted the clinical stage of metastasis and 3 of these genes are related to bone metastasis. ${ }^{[72]}$ CTCs are known for their heterogeneity acquired due to frequent transitions from epithelial to mesenchymal state. Some of these EMT mutations are more frequent in castration-resistant prostate cancer than compared to hormone-sensitive prostate cancer. They can be used to identify specific targets in variants of the same type of cancer. These mutations can be used as a checkpoint and also help to speed up this testing as well as validation of upcoming therapies. In prostate cancer, CTCs have been proposed to act as intermediate or surrogate endpoints for survival and to shorten timelines for drug approval. ${ }^{[73,74]}$

Changes in levels of CTCs can be correlated with the disease status. Patients with lower levels of CTCs have shown slower disease progression in comparison to those having a higher amount of CTCs. ${ }^{[75]} \mathrm{CTCs}$ are sure to provide a better overall picture of the state of disease as there are molecular variations in different sites of metastasis. Shaffer et al. ${ }^{[76]}$ demonstrate an example of variation in EGFR ranging from $0 \%$ to $100 \%$. Hence, understanding the heterogeneity in the disease cannot be understood from the single site biopsy and profiling of these CTCs becomes a necessity. Leversha et al. ${ }^{[77]}$ have shown that molecular characterization of CTCs may be possible for reporting genomic amplification of AR and chromosomal instability in prostate cancer patients. There is very much high expression of MYC and TMPRSS-ETV genes and downregulation of PTEN. ${ }^{[77]}$ Such copy number alterations have been related to aggressive tumors. ${ }^{[78]}$ CTCs exome sequencing has proven its clinical significance. Major percentage of cancer mutations are detected in CTCs, which matched the primary tumor. Furthermore, a great percentage of mutations could be predicted and matched with the metastatic site of tumor. The presence of more than 5 CTCs in $7.5 \mathrm{~mL}$ of blood has been related to poor outcome of the disease treatment in metastasis. ${ }^{[75]}$ Hence, not only is it beneficial in providing prognostic information, but it can also act as a gateway to treat those patients in a better manner whose tumors do not shed CTCs. ${ }^{[79]}$

Newer technologies continue to emerge with the growing research. Lu et al. ${ }^{[34]}$ have introduced NanoVelcro CTCs chip which claims to have better and reproducible results as compared to FDA approved CellSearch ${ }^{\circledR}$ kit. Olmos et $a l .{ }^{[80]}$ have made use of reverse transcription polymerase chain reaction (PCR) to identify telomerase activity in CTCs for which they are very sensitive. However, individual CTCs can be identified with this method. Galletti et al. ${ }^{[81]}$ made use of prostate cancer-specific antibodies i.e. prostate-specific membrane antigen, PSA, prostate specific stem cell antigen and EpCAM to evaluate isolation of CTCs in the metastatic stage of disease which might escape EpCAM specific selection. They have indicated isolation of specific CTCs including the one which undergoes EMT and escape EpCAM selection and organ-specific CTCs in the metastatic stage of prostate cancer. ${ }^{[81]}$

\section{CTCs in Colorectal Cancer Diagnosis and Treatment}

Colorectal cancer (CRC) is one of the most dreaded diseases and has its poor prognosis. Although survival rates have drastically improved over time, timely prognosis would aid the treatment to a great extent using CTCs testing. The data available for earlier stages are yet bare and lacks good sample size for studies on CRC. Romiti et $a .^{[82]}$ have analyzed the prognostic role of CTCs, highlighting the importance of CTCs count before and after chemotherapy. However, to avoid misleading CTCs counts after surgery, it has been suggested that there should be a time gap of at least $24 \mathrm{~h}$ prior to post-surgical sampling. This is because the procedure may contribute to a temporary rise in CTCs which are rapidly cleared within $24 \mathrm{~h}$. CTCs follow-up for patients with the aggressive disease can form an inevitable tool and also help in selecting better emphatic treatments. ${ }^{[82,83]}$ Barbazán et al. ${ }^{[84]}$ have done molecular profiling of CTCs derived from metastatic CRC. They have studied various molecular markers, such as VCL, ITGB5, BMP6 for invasive phenotype, TLN1, APP, CD9, LIMS1, and RSU1 for adhesion and migration for deeper understanding of the behavior of these prostate cancer cells. These markers can be used to profile the type of tumor and to assist in selecting a suitable treatment. In some reports, researchers claim that a higher amount of CTCs is reported in mesenteric blood rather than peripheral blood. CTCs can be used to diagnose patients symptomatic for $\mathrm{CRC}$ in addition to fecal occult and lower gastrointestinal endoscopy. ${ }^{[85]}$ Like other malignancies, dormancy of CTCs in CRC is another aspect to discuss because even after significant exposure to treatment, some CTCs continue to be detected in the circulation. Molnar et al. ${ }^{[86]}$ mention about detection of CTCs as individual cells or as clusters by a CK-based, immunomagnetic cell separation method. Although the number of CTCs decreases with the progressing treatment methods, at least a few of these cells or clusters are observed to be circulating in the blood stream for a long time despite operation. This could be explained by assuming that some CTCs remain dormant in condition for long durations and that they still continue to be present in the circulation.

Mutational analyses of CRC derived CTCs carried out by Bork et al. ${ }^{[87]}$ have pointed out some clinically significant characteristics. In particular, KRAS mutant CTCs are 
discovered in patients, whose primary tumor is KRAS wild type. An ultra-deep sequencing revealed the presence of KRAS mutated group of cells in the primary tumor. This is another example revealing the crucial importance of CTCs sequencing which helps us find out details of the heterogeneity in the tumor which is otherwise not possible by single biopsy. CTCs have been directly related to state to disease and predicting treatment outcome in CRCs just like other cancers. Individual markers such as KRT19, MUC1, EpCAM, CEACAM5, and BIRC5 are studied by de Albuquerque et al. showing positively ranging between $15 \%$ and $35 \%$. They have observed a shorter progression-free survival in patients showing more of these CTCs compared to the group of patients with lesser or no CTCs. ${ }^{[88]}$ In an interesting study by Allen et al., ${ }^{[89]}$ we come across the finding that CRC tumor-associated events such as apoptotic CTCs and CTCs debris are more indicative of liver metastasis in particular than just CTCs count. These events are more indicative of the site of metastasis rather than primary tumor and hence are clinically very significant. ${ }^{[20]} \mathrm{CRC}$ has often been related to liver metastasis in particular. This is supported by detection of increased number of CTCs in mesenteries than peripheral blood. Though the prognostic value of these CTCs has not yet been validated. Denève et al. ${ }^{[90]}$ in their studies strongly support that liver is the filter site for CTCs and that viable CRC disseminated cells can be isolated from hepatic tissue. Reports are pointing out that the EpCAM+ CTCs are often detected in liver indicating a strong signal of association of liver metastasis in CRC. In another study by Antolovic et al. ${ }^{[91]}$ have noted worse overall survival in later stages of CRC patient-derived CTCs having CEA/CK/CD133 positive mRNA than those who are negative for these markers. They have discussed about use of additional markers like CD133 for detection of not only CK20+ and CEA+ subpopulation of CTCs but also for more aggressive type CD133+ disseminated cells.

Improvements in the detection of CTCs continue to evolve as the need does. In one study Antolovic et al. ${ }^{[91]}$ have suggested the use of Ficoll gradient isolation prior to use of EpCAM enrichment technique of CTCs for enhanced results. In many cases, it is easier for clinicians to treat a suffering patient if the malignancy is detected earlier. Hence, in cases such as that of CRC where early detection still awaits some efficient technique, CTCs can play a good enough role in not only detecting and personifying but also providing a real-time means of the disease status along the treatment journey.

\section{CTCs in Lung Cancer Diagnosis and Treatment}

Lung cancer is broadly classified as small cell lung cancer (SCLC) and non-SCLC (NSCLC). Early detection continues to remain a challenge in lung cancer, reducing the chances of survival. Dissemination is an early event in both these types of lung cancer and hence CTCs can be of great use in lung cancer as the available biopsies are not readily procurable. ${ }^{[92-94]}$ A study by
Casavant et al. ${ }^{[93]}$ provides significant data of study on animal models demonstrating use of CTCs in SCLC as "liquid biopsy" and paving way for personalized medicine. The most common methods used for isolating CTCs in lung cancer are CellSearch ${ }^{\circledR}$ and ISET kits. Both these methods indicate a higher number of isolation of CTCs in SCLC than NSCLC. Taenzer et al. ${ }^{[92]}$ have explained this by the possibility of EMT in NSCLC, which makes the disseminated cells escape EpCAM selection. Mutations on exon 19 and 21 of EGFR are the prime target of drug-based therapies. Other mutations such as T790M, EML4-ALK rearrangement, BRAF, KRAS, HER2, PIK3CA/AKT1, ROS, FGFR1, and MET are also of greater interest in lung cancer as clinical trials are now focused on mutation based therapies. $^{[95,96]}$ Molecular characterization of CTCs holds great importance as it can provide a very plausible means of mutation detection. Furthermore, one can be easily monitored periodically for the development of any resistant mutations during the course of treatment. ${ }^{[97-99]}$ Higher number CTCs in lung cancer has been associated with larger tumor size and in particular in bone metastasis. ${ }^{[100-102]}$ CTCs have surely gathered lot of enthusiasm and effort towards their research with their staggering clinical potentials. But till date research on them has been limited by many factors, such as their small capture number being a major problem. Kolostova et al. ${ }^{[35]}$ have drawn an attractive protocol for isolation and culturing in vitro CTCs of human lung cancer. If CTCs can be cultured in vitro like other cells, it will be of great beneficial value as it will pace up the investigation on the nature of CTCs and its characterization. Furthermore, circulating tumor micro-emboli (CTMs) have been reported in many cases of lung cancer. CTMs are cluster of disseminated tumor cells in circulation. CTM are of particular interest in this case as they are considered to be markers of extreme metastatic potential. ${ }^{[103]}$ Treatment response is a major question in advanced lung cancer. CTCs count can potentially help approve the ongoing treatment and also help in suggesting any alterations if required. ${ }^{[104,105]}$ Ilie et al. ${ }^{[105]}$ in their discussion on CTCs in lung cancer have indicated possibilities of the presence of these cells even before angiogenesis. CTCs can be present in circulation long time before the disease can be actually detected. Therefore, they can become the core of research in regards of early detection of the disease for symptomatic patients. ${ }^{[106-108]}$

\section{CTCs in Other Cancers Diagnosis and Treatment}

CTCs can be detected in almost all of the solid tumor malignancies and changes in the disease state can be predicted with the help of CTCs. Genes like VIM, TGFBR2, TGFB, and SERPINE1 which are indicative of mesenchymal phenotype, are expressed in higher levels in the CTCs of glioblastoma cancer in comparison to the cells of the primary tumor or cell culture. ${ }^{[109-111]}$ TWIST and Vimentin are considered as diagnostic markers for hepatocellular carcinoma. TWIST is known to suppress expression of E-cadherin while overexpression 
of Vimentin is strongly related with the mesenchymal phenotype of these CTCs. Overexpression of ZEB1 and ZEB2 is also reported in this cancer. ${ }^{[112]}$ So far, no specific marker has been reported for bladder cancer. However, it has been suggested that overexpression of H-RAS oncogene and mutations in $F G R-R$ genes in CTCs could be considered as a diagnostic tool. ${ }^{[113]}$ Apart from genes, other cellular transformations like loss of cellular junctions which aid in cell to cell communications are indicative of mesenchymal phenotype. Markers such as CK20, UP II, and EGFR have been related to diagnosis of bladder cancer. CTCs can be assessed to detect the presence of these markers and aid in the diagnosis of the malignancy. ${ }^{[14,115]}$ Alonso-Alconada et al. ${ }^{[41]}$ have done molecular profiling of CTCs isolated from metastatic endometrial carcinoma (EC) patients. They have shown that there is an overexpression of stem cell related genes, i.e. ALDH and CD44, EC related genes such as $B R A F$, $P I K 3 C A, R E L A, R U N X 1$, and EMT related genes, that is, ETV5, NOTCH1, SNAI1, TGFB1, ZEB1 in these patients. ${ }^{[41]}$ Of these genes, ETV5, in particular, is strongly related to increased metastasis and CTCs plasticity. ${ }^{[41]}$ Häfner et al. ${ }^{[116]}$ have shown that the evaluation of level of HPV16-E6 mRNA by real-time PCR is more sensitive molecular marker expressed in CTCs isolated from metastatic cervical cancer patients than that of commonly used CK19 mRNA as a marker. Just like other solid tumors, in case of pancreatic cancer, several studies have similarly suggested the use of CTCs for not only diagnosing but also for identifying metastasis in patients and helping to select patient-specific therapies. ${ }^{[117-119]} \mathrm{A}$ study by Kuhlmann et al. ${ }^{[120]}$ brings to light an importance of the molecular characterization of CTCs in ovarian cancer. They have shown that ERCC1+ CTCs can predict platinum resistance therapy in ovarian cancer which is still remains a big challenge in the treatment of ovarian malignancy. ${ }^{[120]}$ Obermayer et al. ${ }^{[121]}$ have shown that there are more number of cyclophilin $\mathrm{C}$ gene (PPIC) positive CTCs are detected usually in ovarian platinum-resistant cancer group as compared to the sensitive group than EpCAM positive CTCs in these patients. It is also related to poor outcomes of this disease. ${ }^{[121]}$ Advancements in CTCs detection techniques have given rise to newer methods, such as the one-step detection of using fluorescent silica nanoparticles for ovarian cancer. ${ }^{[122]}$ With the growing technologies and persistent work on CTCs, we are slowly channelizing the efforts to derive a clearer picture of the use of CTCs in diagnosis and treatment of various cancers.

\section{Future Directions}

Taken together, CTCs have potential to aid in the entire course of a patient's cancer journey starting from diagnosis, treatment selection, post-treatment/surgery monitoring, and follow-up. Although vast amount of research have been accelerated in the field of these disseminated tumor cells, their availability in scant

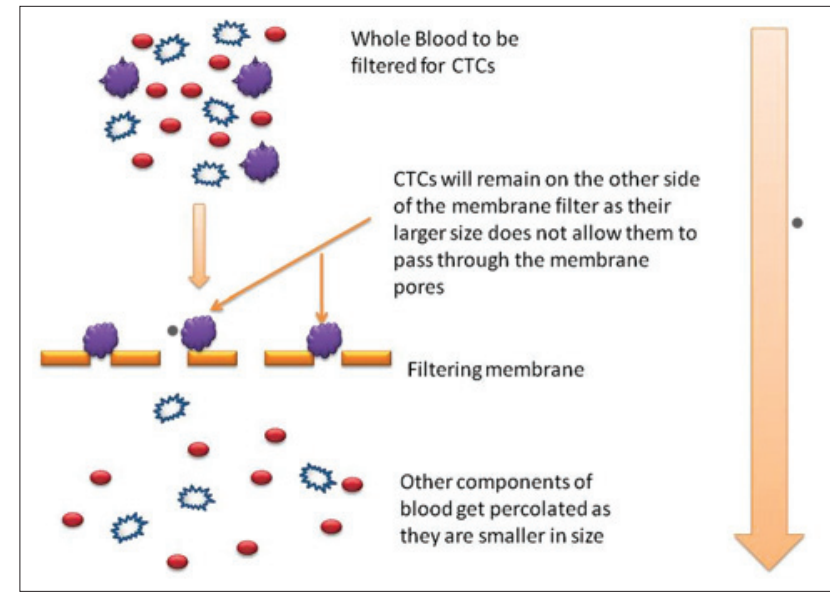

Figure 5: Size-based separation of circulating tumor cells

numbers has limited research. We anticipate the development of isolation and enrichment combination techniques which help in avoiding cell loss. A range of specific markers is also bound to enhance the enrichment results as those cells which can escape EpCAM selection could also be captured. Given their tremendous potential to help change the enigmatic situation of solid tumors, we can conclude that CTCs are sure to become an inevitable part in the near future of solid tumors malignancies.

\section{Acknowledgments}

Authors wish to acknowledge Management of Jaslok Hospital and Research Centre, Mumbai for providing facilities to establish CSC laboratory in the Department of Molecular Medicine and Biology. This gave an excellent exposure to develop this important technology in this laboratory and thus to write such an important review on this topic.

\section{References}

1. Gavhane YN, Shete AS, Bhagat AK, Shinde VR, Bhong KK, Khairnar GA, Yadav AV. Solid tumors: facts, challenges and solutions. Int J Pharm Sci Res 2011;2:1-12.

2. Bedard PL, Hansen AR, Ratain MJ, Siu LL. Tumorheterogeneity in the clinic. Nature 2013;501:355-64.

3. Greaves M, Maley CC. Clonal evolution in cancer. Nature 2012;481:306-13

4. Holohan C, Van Schaeybroeck S, Longley DB, Johnston PG. Cancer drug resistance: an evolving paradigm. Nat Rev Cancer 2013;13:714-26.

5. Bogenrieder T, Herlyn M. Axis of evil: Molecular mechanisms of cancer metastasis. Oncogene 2003;22:6524-36.

6. Kleiner DE, Stetler-Stevenson WG. Matrix metalloproteinases and metastasis. Cancer Chemother Pharmacol 1999;43 Suppl: S42-51.

7. Chaffer CL, Weinberg RA. A perspective on cancer cell metastasis. Science 2011;331:1559-64.

8. Micalizzi DS, Farabaugh SM, Ford HL. Epithelial-mesenchymal transition in cancer: parallels between normal development and tumour progression. J Mammary Gland Biol Neoplasia 2010;15:117-34.

9. Carmeliet P, Jain RK. Angiogenesis in cancer and other diseases. Nature 2000;407:249-57.

10. Yap TA, Lorente D, Omlin A, Olmos D, de Bono JS. Circulating tumour cells: a multifunctional biomarker. Clin 
Cancer Res 2014;20:2553-68.

11. Plaks V, Koopman CD, Werb Z. Cancer. Circulating tumour cells. Science 2013;341:1186-8.

12. Nakaya Y, Sheng G. EMT in developmental morphogenesis. Cancer Lett 2013;341:9-15.

13. de Wit S, van Dalum G, Terstappen LW. Detection of circulating tumour cells. Scientifica (Cairo) 2014;2014:819362.

14. Krebs MG, Metcalf RL, Carter L, Brady G, Blackhall FH, Dive C. Molecular analysis of circulating tumour cells-biology and biomarkers. Nat Rev Clin Oncol 2014;11:129-44.

15. Krebs MG, Hou JM, Ward TH, Blackhall FH, Dive C. Circulating tumour cells: their utility in cancer management and predicting outcomes. Ther Adv Med Oncol 2010;2:351-65.

16. King JD, Casavant BP, Lang JM. Rapid translation of circulating tumour cell biomarkers into clinical practice: technology developmet, clinical needs and regulatory requirements. Lab Chip 2014;14:24-31.

17. Balic M, Dandachi N, Lin H, Datar RH. Cancer metastasis: advances in the detection and characterization of disseminated tumour cells facilitate clinical translation. Natl Med J India 2005; 18:250-5.

18. Riethdorf S, Müller V, Zhang L, Rau T, Loibl S, Komor M, Roller M, Huober J, Fehm T, Schrader I, Hilfrich J, Holms F, Tesch H, Eidtmann H, Untch M, von Minckwitz G, Pantel K. Detection and HER2 expression of circulating tumour cells: prospective monitoring in breast cancer patients treated in the neoadjuvant GeparQuattro trial. Clin Cancer Res 2010;16:2634-45.

19. Singh A, Settleman J. EMT, cancer stem cells and drug resistance: an emerging axis of evil in the war on cancer. Oncogene 2010;29:4741-51.

20. Nesteruk D, Rutkowski A, Fabisiewicz S, Pawlak J, Siedlecki JA, Fabisiewicz A. Evaluation of prognostic significance of circulating tumor cells detection in rectal cancer patients treated with preoperative radiotherapy: prospectively collected material data. Biomed Res Int 2014;2014:712827.

21. Alix-Panabières C, Pantel K. Technologies for detection of circulating tumour cells: facts and vision. Lab Chip 2014; 14:57-62.

22. Gertler R, Rosenberg R, Fuehrer K, Dahm M, Nekarda H, Siewert JR. Detection of circulating tumor cells in blood using an optimized density gradient centrifugation. Recent Results Cancer Res 2003;162:149-55.

23. Lustberg M, Jatana KR, Zborowski M, Chalmers JJ. Emerging technologies for CTC detection based on depletion of normal cells. Recent Results Cancer Res 2012;195:97-110.

24. Gerges N, Rak J, Jabado N. New technologies for the detection of circulating tumour cells. Br Med Bull 2010;94:49-64.

25. Sun YF, Yang XR, Zhou J, Qiu SJ, Fan J Xu Y. Circulating tumor cells: advances in detection methods, biological issues, and clinical relevance. J Cancer Res Clin Oncol 2011;137:1151-73.

26. Yu M, Stott S, Toner M, Maheswaran S, Haber DA. Circulating tumor cells: approaches to isolation and characterization. J Cell Biol 2011;192:373-82.

27. Chen P, Huang YY, Hoshino K, Zhang X. Multiscale immunomagnetic enrichment of circulating tumour cells: from tubes to microchips. Lab Chip 2014;14:446-58.

28. Karabacak NM, Spuhler PS, Fachin F, Lim EJ, Pai V, Ozkumur E, Martel JM, Kojic N, Smith K, Chen PI, Yang J, Hwang H, Morgan B, Trautwein J, Barber TA, Stott SL, Maheswaran S, Kapur R, Haber DA, Toner M. Microfluidic, marker-free isolation of circulating tumour cells from blood samples. Nat Protoc 2014;9:694-710.
29. Jackson JM, Witek MA, Hupert ML, Brady C, Pullagurla S, Kamande J, Aufforth RD, Tignanelli CJ, Torphy RJ, Yeh JJ, Soper SA. UV activation of polymeric high ascpect ratio microstructures: ramifications in antibody surface loading for circulating tumour cell. Lab Chip 2014;14:106-17.

30. Weltin A, Slotwinski K, Kieninger J, Moser I, Jobst G, Wego M, Ehret R, Urban GA. Cell culture monitoring for drug screening and cancer research: a transparent, microfluidic, multi-sensor microsystem. Lab Chip 2014;14:138-46.

31. Hyun KA, Jung HI. Advances and critical concerns with the microfluidic enrichments of circulating tumour cells. Lab Chip 2014;14:45-56.

32. Vona G, Sabile A, Louha M, Sitruk V, Romana S, Schütze K, Capron F, Franco D, Pazzagli M, Vekemans M, Lacour B, Bréchot $\mathrm{C}$, Paterlini-Bréchot $\mathrm{P}$. Isolation by size of epithelial tumor cells. Am J Pathol 2000;156:57-63.

33. Peeters DJ, De Laere B, Van den Eynden GG, Van Laere SJ, Rothé F, Ignatiadis M, Sieuwerts AM, Lambrechts D, Rutten A, van Dam PA, Pauwels P, Peeters M, Vermeulen PB, Dirix LY. Semiautomated isolation and molecular characterisation of single or highly purified tumour cells from CellSearch enriched blood samples using dielectrophoretic cell sorting. Br J Cancer 2013;108:1358-67.

34. Lu YT, Zhao L, Shen Q, Garcia MA, Wu D, Hou S, Song M, $\mathrm{Xu} \mathrm{X}$, Ouyang WH, Ouyang WW, Lichterman J, Luo Z, Xuan X, Huang J, Chung LW, Rettig M, Tseng HR, Shao C, Posadas EM. NanoVelcro Chip for CTC enumeration in prostate cancer patients. Methods 2013;64:144-52.

35. Kolostova K, Zhang Y, Hoffman RM, Bobek V. In vitro culture and characterization of human lung cancer circulating tumor cells isolated by size exclusion from an orthotopic nude-mouse model expressing fluorescent protein. $J$ Fluoresc 2014;24:1531-6.

36. Ju M, Kao GD, Simone CB, Steinmetz D, Xu XS, Aguarin L, Xu W, Bartlett E, Hahn SM, Dorsey JF, Karakousis G. "Capturing the elusive foe": a novel telomerase promoter-based approach to detect melanoma circulating tumour cells. Cancer Res 2014;74:1871.

37. Casavant BP, Guckenberger DJ, Berry SM, Tokar JT, Lang JM, Beebe DJ. The VerIFAST: an integrated method for cell isolation and extracellular/intracellular staining. Lap Chip 2013;13:391-6.

38. Jin C, McFaul SM, Duffy SP, Deng X, Tavassoli P, Black PC, Ma H. Technologies for label-free separation of circulating tumour cells: from historical foundations to recent developments. Lab Chip 2014;14:32-44.

39. Krawczyk N, Meier-Stiegen F, Banys M, Neubauer H, Ruckhaeberle E, Fehm T. Expression of Stem Cell and Epithelial-Mesenchymal Transition Markers in Circulating Tumor Cells of Breast Cancer Patients. Biomed Res Int 2014;2014:415721.

40. Khan MA, Chen HC, Zhang D, Fu J. Twist: a molecular target in cancer therapeutics. Tumor Biol 2013;34:2497-506.

41. Alonso-Alconada L, Muinelo-Romay L, Madissoo K, Diaz-Lopez A, Krakstad C, Trovik J, Wik E, Hapangama D, Coenegrachts L, Cano A, Gil-Moreno A, Chiva L, Cueva J, Vieito M, Ortega E, Mariscal J, Colas E, Castellvi J, Cusido M, Dolcet X, Nijman HW, Bosse T, Green JA, Romano A, Reventos J, Lopez-Lopez R, Salvesen HB, Amant F, Matias-Guiu X, Moreno-Bueno G, Abal M1; ENITEC Consortium. Molecular profiling of circulating tumour cells links plasticity to the metastatic process in endometrial cancer. Mol Cancer 2014;13:223.

42. Nagrath S, Sequist LV, Maheswaran S, Bell DW, Irimia D, Ulkus L, Smith MR, Kwak EL, Digumarthy S, Muzikansky A, 
Ryan P, Balis UJ, Tompkins RG, Haber DA, Toner M. Isolation of rare circulating tumour cells in cancer patients by microchip technology. Nature 2007;450:1235-9.

43. Chen CL, Osmulski P, Mahalingum D, Horning AM, Jadhav RR, Louie AD, Wang CM, Huang THM. Epithelial-to-mesenchymal markers of circulating tumour cells for detection of castration-resistant prostate cancer. Cancer Res 2014;74:5588.

44. Galletti G, Sung MS, Vahdat LT, Shah MA, Santana SM, Altavilla G, Kirby BJ, Giannakakou P. Isolation of breast cancer and gastric circulating tumour cells by use of an anti HER2-based microfluidic device. Lab Chip 2014;14:147-56.

45. Armstrong AJ, Marengo MS, Oltean S, Kemeny G, Bitting RL, Turnbull JD, Herold CI, Marcom PK, George DJ, Garcia-Blanco MA. Circulating tumour cells from patients with advanced prostate and breast cancer display both epithelial and mesenchymal markers. Mol Cancer Res 2011;9:997-1007.

46. Smirnov DA, Zweitzig DR, Foulk BW, Miller MC, Doyle GV, Pienta KJ, Meropol NJ, Weiner LM, Cohen SJ, Moreno JG, Connelly MC, Terstappen LW, O'Hara SM. Global gene expression profiling of circulating tumour cells. Cancer Res 2005;65:4993-7.

47. Williams A, Rawal S, Ao Z, Lu B, Toress-Munoz J, Rini B, Pelley R, Budd GT, Borden E, Zheng S, Datar R, Tai YC, Cote R. Capture and molecular characterization of CTC in metastatic breast, prostate, colorectal and renal cancer. Cancer Res 2012;72:2372.

48. Haber DA, Maheshwaran S, Sequist L, Yu M, Ozkummur E, Ting D, Miyamoto D, Lee R, Shah A, Bardia A, Stott S, Toner M. Molecular characterization of circulating tumour cells. Mol Cancer Ther 2013;12:PL06-04. (Abstract).

49. Schölch S, Bork U, Rahbari NN, García S, Swiersy A, Betzler AM, Weitz J, Koch M. Circulating tumor cells of colorectal cancer. Cancer Cell Microenviron 2014;1:e323.

50. Aceto N, Bardia A, Miyamoto DT, Donaldson MC, Wittner BS, Spencer JA, Yu M, Pely A, Engstrom A, Zhu H, Brannigan BW, Kapur R, Stott SL, Shioda T, Ramaswamy S, Ting DT, Lin CP, Toner M, Haber DA, Maheswaran S. Circulating tumour cell clusters are oligoclonal precursors of breast cancer metastasis. Cell 2014;158:1110-22.

51. Bidard FC, Vincent-Salomon A, Sigal-Zafrani B, Diéras V, Mathiot C, Mignot L, Thiery JP, Sastre-Garau X, Pierga JY. Prognosis of women with stage IV breast cancer depends on detection of circulating tumour cells rather than disseminated tumour cells. Ann Oncol 2008;19:496-500.

52. Rack B, Schindlbeck C, Jückstock J, Andergassen U, Hepp P, Zwingers T, Friedl TW, Lorenz R, Tesch H, Fasching PA, Fehm T, Schneeweiss A, Lichtenegger W, Beckmann MW, Friese K, Pantel K, Janni W; SUCCESS Study Group. Circulating tumor cells predict survival in early average-to-high risk breast cancer patients. J Natl Cancer Inst 2014;106:dju066.

53. Lianidou ES, Markou A. Ciculating tumour cells in breast cancer: Detection systems, molecular characterization, and future challenges. Clin Chem 2011;57:1242-55.

54. Fernandez SV, Bingham C, Fittipaldi P, Austin L, Palazzo J, Palmer G, Alpaugh K, Cristofanilli M. TP53 mutations detected in circulating tumour cells present in the blood of metastatic triple negative breast cancer patients. Breast Cancer Res 2014;16:445.

55. Swaby RF, Cristofanilli M. Circulating tumor cells in breast cancer: a tool whose time has come of age. BMC Med 2011;9:43.

56. Obermayr E, Sanchez-Cabo F, Tea MM, Singer CF, Krainer M,
Fischer MB. Assessment of a six gene panel for the molecular detection of circulating tumor cells in the blood of female cancer patients. BMC Cancer 2010;10:666.

57. Polzer B, Medoro G, Pasch S, Fontana F, Zorzino L, Pestka A, Andergassen U, Meier-Stiegen F, Czyz ZT, Alberter B, Treitschke S, Schamberger T, Sergio M, Bregola G, Doffini A, Gianni S, Calanca A, Signorini G, Bolognesi C, Hartmann A, Fasching PA, Sandri MT, Rack B, Fehm T, Giorgini G, Manaresi N, Klein CA. Molecular profiling of single circulating tumor cells with diagnostic intention. EMBO Mol Med 2014;6:1371-86.

58. Bredemeier M, Aktas B, Kimmig R, Kasimir-Bauer S. Establishment of a multimarker gene panel for the characterization of circulating tumor cells in metastatic breast cancer. Cancer Res 2013;73:1466.

59. Mirantes C, Espinosa I, Ferrer I, Dolcet X, Prat J, Matias-Guiu X. Epithelial-tomesenchymal transition and stem cells in endometrial cancer. Hum Pathol 2013;44:1973-81.

60. Wik E, Ræder MB, Krakstad C, Trovik J, Birkeland E, Hoivik EA, Mjos S, Werner HM, Mannelqvist M, Stefansson IM, Oyan AM, Kalland KH, Akslen LA, Salvesen HB. Lack of estrogen receptor- $\alpha$ is associated with epithelial-mesenchymal transition and PI3K alterations in endometrial carcinoma. Clin Cancer Res 2013;19:1094-105.

61. Powell AA, Talasaz AH, Zhang H, Coram MA, Reddy A, Deng G, Telli ML, Advani RH, Carlson RW, Mollick JA, Sheth S, Kurian AW, Ford JM, Stockdale FE, Quake SR, Pease RF, Mindrinos MN, Bhanot G, Dairkee SH, Davis RW, Jeffrey SS. Single cell profiling of circulating tumour cells: transcriptional heterogeneity and diversity from breast cancer cell lines. PLoS One 2012;7:e33788.

62. Königsberg R, Obermayr E, Bises G, Pfeiler G, Gneist M, Wrba F, de Santis M, Zeillinger R, Hudec M, Dittrich C. Detection of EpCAM positive and negative circulating tumor cells in metastatic breast cancer patients. Acta Oncol 2011;50:700-10.

63. Brugger W, Bross KJ, Glatt M, Weber F, Mertelsmann R, Kanz L. Mobilization of tumor cells and hematopoietic progenitor cells into peripheral blood of patients with solid tumor. Blood 1994;83:636-40.

64. Peeters DJ, van Dam PJ, Van den Eynden GG, Rutten A, Wuyts H, Pouillon L, Peeters M, Pauwels P, Van Laere SJ, van Dam PA, Vermeulen PB, Dirix LY. Detection and prognostic significance of circulating tumour cells in patients with metastatic breast cancer according to immunohistochemical subtypes. Br J Cancer 2014;110:375-83.

65. Smerage JB, Barlow WE, Hortobagyi GN, Winer EP, Leyland-Jones B, Srkalovic G, Tejwani S, Schott AF, O'Rourke MA, Lew DL, Doyle GV, Gralow JR, Livingston RB, Hayes DF. Circulating Tumor cells and response to chemotherapy in metastatic breast cancer: SWOG S0500. J Clin Oncol 2014;256:251.

66. Martelotto LG, Ng CK, Piscuoglio S, Weigelt B, Reis-Filho JS. Breast cancer intra-tumor heterogeneity. Breast Cancer Res 2014;16:210,

67. Dittamore R, Louw J, Krupa R, Anand A, Danila DC, ArslanZ, Bales N, Marrinucci D, Scher HI. Molecular characteriszation of circulating tumour cells (CTC) and CTC subpopulations in baseline and progressive metastatic castration resistant prostate cancer (mCRPC). J Clin Oncol 2014;32:abstr e16018.

68. Hoogland AM, Kweldam CF, van Leenders GJ. Prognostic histopathological and molecular markers on prostate cancer needle-biopsies: a review. Biomed Res Int 2014;2014:341324.

69. Miyamoto DT, Lee RJ, Stott SL, Ting DT, Wittner BS, Ulman M, Smas ME, Lord JB, Brannigan BW, Trautwein J, Bander NH, Wu CL, Sequist LV, Smith MR, Ramaswamy S, 
Toner M, Maheswaran S, Haber DA. Androgen receptor signalling in circulating tumor cells as a marker of hormonally responsive prostate cancer. Cancer Discov 2012;2:995-1003.

70. Attard G, Swennenhuis JF, Olmos D, Reid AH, Vickers E, A'Hern R, Levink R, Coumans F, Moreira J, Riisnaes R, Oommen NB, Hawche G, Jameson C, Thompson E, Sipkema R, Carden CP, Parker C, Dearnaley D, Kaye SB, Cooper CS, Molina A, Cox ME, Terstappen LW, de Bono JS. Characterization of ERG, AR and PTEN gene status in circulating tumor cells from patients with castration-resistant prostate cancer. Cancer Res 2009;69:2912-8.

71. Giesing M, Suchy B, Driesel G, Molitor D. Clinical utility of antioxidant gene expression levels in circulating cancer cell clusters for the detection of prostate cancer in patients with prostate-specific antigen levels of $4-10 \mathrm{ng} / \mathrm{mL}$ and disease prognostication after radical prostatectomy. BJU Int 2010;105:1000-10.

72. Hu B, Rochefort H, Goldkorn A. Circulating tumor cells in prostate cancer. Cancers 2013;5:1676-90.

73. de Bono JS, Scher HI, Montgomery RB, Parker C, Miller MC, Tissing H, Doyle GV, Terstappen LW, Pienta KJ, Raghavan D. Circulating tumor cells predict survival benefit from treatment in metastatic castration-resistant prostate cancer. Clin Cancer Res 2008;14:6302-9.

74. Scher HI, Beer TM, Higano CS, Anand A, Taplin ME, Efstathiou E, Rathkopf D, Shelkey J, Yu EY, Alumkal J, Hung D, Hirmand M, Seely L, Morris MJ, Danila DC, Humm J, Larson S, Fleisher M, Sawyers CL; Prostate Cancer Foundation/Department of Defense Prostate Cancer Clinical Trials Consortium. Antitumour activity of MDV3100 in castration-resistant prostate cancer: a phase 1-2 study. Lancet 2010;375:1437-46.

75. Moreno JG, Miller MC, Gross S, Allard WJ, Gomella LG, Terstappen LW. Circulating tumor cells predict survival in patients with metastatic prostate cancer. Urology 2005;65:713-8.

76. Shaffer DR, Leversha MA, Danila DC, Lin O, Gonzalez-Espinoza R, Gu B, Anand A, Smith K, Maslak P, Doyle GV, Terstappen LW, Lilja H, Heller G, Fleisher M, Scher HI. Circulating tumor cell analysis in patients with progressive castration-resistant prostate cancer. Clin Cancer Res 2007;13:2023-9.

77. Leversha MA, Han J, Asgari Z, Danila DC, Lin O, Gonzalez-Espinoza R, Anand A, Lilja H, Heller G, Fleisher M, Scher HI. Fluorescence in situ hybridization analysis of circulating tumor cells in metastatic prostate cancer. Clin Cancer Res 2009;15:2091-7.

78. Danila DC, Fleisher M, Scher HI. Circulating tumor cells as biomarkers in prostate cancer. Clin Cancer Res 2011;17:3903-12.

79. Danila DC, Heller G, Gignac GA, Gonzalez-Espinoza R, Anand A, Tanaka E, Lilja H, Schwartz L, Larson S, Fleisher M, Scher HI. Circulating tumor cell number and prognosis in progressive castration-resistant prostate cancer. Clin Cancer Res 2007;13:7053-8.

80. Olmos D, Arkenau HT, Ang JE, Ledaki I, Attard G, Carden CP, Reid AH, A'Hern R, Fong PC, Oomen NB, Molife R, Dearnaley D, Parker C, Terstappen LW, de Bono JS. Circulating tumour cell (CTC) counts as intermediate end points in castration-resistant prostate cancer (CRPC): a single-centre experience. Ann Oncol 2009;20:27-33.

81. Galletti G, Portella L, Tagawa ST, Kirby BJ, Giannakakou P, Nanus DM. Circulating tumor cells in prostate cancer diagnosis and monitoring: an appraisal of clinical potential.
Mol Diagn Ther 2014;18:389-402.

82. Romiti A, Raffa S, Di Rocco R, Roberto M, Milano A, Zullo A, Leone L, Ranieri D, Mazzetta F, Medda E, Sarcina I, Barucca V, D'Antonio C, Durante V, Ferri M, Torrisi MR, Marchetti P. Circulating tumor cells count predicts survival in colorectal cancer patients. $J$ Gastrointestin Liver Dis 2014;23:279-84.

83. van Dalum G, Stam GJ, Scholten LF, Mastboom WJ, Vermes I, Tibbe AG, De Groot MR, Terstappen LW. Importance of circulating tumor cells in newly diagnosed colorectal cancer. Int J Oncol 2015;46:1361-8.

84. Barbazán J, Alonso-Alconada L, Muinelo-Romay L, Vieito M, Abalo A, Alonso-Nocelo M, Candamio S, Gallardo E, Fernández B, Abdulkader I, de Los Ángeles Casares M, Gómez-Tato A, López-López R, Abal M. Molecular characterization of circulating tumor cells in human metastatic colorectal cancer. PLoS One 2012;7:e40476.

85. Loveday RL, Titu L, Beral D, Jordison VL, Monson JR, Greenman J. Telomerase activity in circulating colorectal tumour cells. Cancer Ther 2004;2:115-20.

86. Molnar B, Ladanyi A, Tanko L, Sréter L, Tulassay Z. Circulating tumor cell clusters in the peripheral blood of colorectal cancer patients. Clin Cancer Res 2001;7:4080-5.

87. Bork U, Rahbari NN, Schölch S, Reissfelder C, Kahlert C, Büchler MW, Weitz J, Koch M. Circulating tumour cells and outcome in non-metastatic colorectal cancer: a prospective study. Br J Cancer 2014;112:1306-13.

88. de Albuquerque A, Kubisch I, Stölzel U, Ernst D, Boese-Landgraf J, Breier G, Stamminger G, Fersis N, Kaul S. Prognostic and predictive value of circulating tumor cell analysis in colorectal cancer patients. $J$ Transl Med 2012;10:222.

89. Allen JE, Saroya BS, Kunkel M, Dicker DT, Das A, Peters KL, Joudeh J, Zhu J, El-Deiry WS. Apoptotic circulating tumor cells (CTCs) in the peripheral blood of metastatic colorectal cancer patients are associated with liver metastasis but not CTCs. Oncotarget 2014;5:1753-60.

90. Denève E, Riethdorf S, Ramos J, Nocca D, Coffy A, Daurès JP, Maudelonde T, Fabre JM, Pantel K, Alix-Panabières C. Capture of viable circulating tumor cells in the liver of colorectal cancer patients. Clin Chem 2013;59:1384-92.

91. Antolovic D, Galindo L, Carstens A, Rahbari N, Büchler MW, Weitz J, Koch M. Heterogeneous detection of circulating tumor cells in patients with colorectal cancer by immunomagnetic enrichment using different EpCAM-specific antibodies. BMC Biotechnol 2010;10:35.

92. Taenzer A, Alix-Panabières C, Wikman H, Pantel K. Circulating tumor-derived biomarkers in lung cancer. $J$ Thorac Dis 2012;4:448-9.

93. Casavant BP, Strotman LN, Tokar JJ, Thiede SM, Traynor AM, Ferguson JS, Lang JM, Beebe DJ. Paired diagnostic and pharmacodynamic analysis of rare non-small cells lung cancer cells enabled by the VerIFAST platform. Lab Chip 2014;14:99-105.

94. Zhang MH, Chi D, Zhao S, Wang Y, Yang MP, Wang Y. Circulating tumor cells in lung cancer: Detection methods and clinical impact. Chin German J Clin Oncol 2014;13:476-82.

95. Hodgkinson CL, Morrow CJ, Li Y, Metcalf RL, Rothwell DG, Trapani F, Polanski R, Burt DJ, Simpson KL, Morris K, Pepper SD, Nonaka D, Greystoke A, Kelly P, Bola B, Krebs MG, Antonello J, Ayub M, Faulkner S, Priest L, Carter L, Tate C, Miller CJ, Blackhall F, Brady G, Dive C. Tumorigenicity and genetic profiling of circulating tumor cells in small-cell lung cancer. Nat Med 2014;20:897-903. 
96. Punnoose EA, Atwal S, Liu W, Raja R, Fine BM, Hughes BG, Hicks RJ, Hampton GM, Amler LC, Pirzkall A, Lackner MR. Evaluation of circulating tumor cells and circulating tumor DNA in non-small cell lung cancer: association with clinical endpoints in a phase II clinical trial of pertuzumab and erlotinib. Clin Cancer Res 2012;18:2391-401.

97. Hofman V, Ilie M, Long E, Guibert N, Selva E, Washetine K, Mograbi B, Mouroux J, Vénissac N, Reverso-Meinietti J, Milano G, Mazières J, Marquette $\mathrm{CH}$, Paterlini-Bréchot $\mathrm{P}$, Hofman P. Detection of circulating tumor cells from lung cancer patients in the era of targeted therapy: promises, drawbacks and pitfalls. Curr Mol Med 2014;14:440-56.

98. Boshuizen R, Kuhn P, van den Heuvel M. Circulating tumor cells in non-small cell lung carcinoma. J Thorac Dis 2012;4: 456-8.

99. Maheswaran S, Sequist LV, Nagrath S, Ulkus L, Brannigan B, Collura CV, Inserra E, Diederichs S, Iafrate AJ, Bell DW, Digumarthy S, Muzikansky A, Irimia D, Settleman J, Tompkins RG, Lynch TJ, Toner M, Haber DA. Detection of mutations in EGFR in circulating lung-cancer cells. N Engl J Med 2008;359:366-77.

100. Nel I, Jehn U, Gauler T, Hoffmann AC. Individual profiling of circulating tumor cell composition in patients with non-small cell lung cancer receiving platinum based treatment. Transl Lung Cancer Res 2014;3:100-6.

101. Tanaka F, Yoneda K, Hasegawa S. Circulating tumor cells (CTCs) in lung cancer: Current status and future perspectives. Lung Cancer Targets Ther 2010;1:77-84.

102. Cheng M, Liu L, Yang HS, Liu GF. Circulating tumor cells are associated with bone metastasis of lung cancer. Asian Pac $J$ Cancer Prev 2014;15:6369-74.

103. Hou JM, Krebs M, Ward T, Morris K, Sloane R, Blackhall F, Dive C. Circulating tumor cells, enumeration and beyond. Cancers (Basel) 2010;2:1236-50.

104. Krebs MG, Sloane R, Priest L, Lancashire L, Hou JM, Greystoke A, Ward TH, Ferraldeschi R, Hughes A, Clack G, Ranson M, Dive C, Blackhall FH. Evaluation and prognostic significance of circulating tumor cells in patients with non-small-cell lung cancer. $J$ Clin Oncol 2011;29:1556-63.

105. Ilie M, Hofman V, Long-Mira E, Selva E, Vignaud JM, Padovani B, Mouroux J, Marquette CH, Hofman P. "Sentinel" circulating tumor cells allow early diagnosis of lung cancer in patients with chronic obstructive pulmonary disease. PLoS One 2014;9:e111597.

106. Yang SH, Yang YS. Circulating tumor cells in lung cancer. J Lung Cancer 2011;10:13-25.

107. Wong MP. Circulating tumor cells as lung cancer biomarkers. $J$ Thorac Dis 2012;4:631-4.

108. Olmedo ME, Mezquita L, Earl J, Benito A, Santon A, Longo F, Vallejo C, Muñoz G, Gorospe L, Soria A, Gordoa TA, Grande E, Roberts E, Gomez A, Gortez P, Alcalde R, Muñoz J, Cortés A, Garrido P. Monitoring circulating tumor cells (CTC) in lung cancer: preliminary results. Ann Oncol 2014;25:iv83.

109. Sullivan JP1, Nahed BV, Madden MW, Oliveira SM, Springer S, Bhere D, Chi AS, Wakimoto H, Rothenberg SM, Sequist LV, Kapur R, Shah K, Iafrate AJ, Curry WT, Loeffler JS, Batchelor TT, Louis DN, Toner M, Maheswaran S, Haber DA. Brain tumor cells in circulation are enriched for mesenchymal gene expression. Cancer Discov 2014;4:1299-309.

110. Sullivan JP, Nahed BV, Chi AS, Madden MN, Oliveira SM, Springer S, Wakimoto H, Bhere D, Shah K, Spuhler P, Shah AM, Louis DN, Toner M, Maheswaran S, Haber DA. Molecular characterization of circulating glioblastoma cells indentifies a mescenchymal-like tumour cell subpolulation. Cancer Res 2014;74:4004.

111. Grisanti S, Almici C, Consoli F, Buglione M, Verardi R, Bolzoni-Villaret A, Bianchetti A, Ciccarese C, Mangoni M, Ferrari L, Biti G, Marini M, Ferrari VD, Nicolai P, Magrini SM, Berruti A. Circulating tumor cells in patients with recurrent or metastatic head and neck carcinoma: Prognostic and predictive significance. PLoS One 2014;9:e103918.

112. Zhou YM, Cao L, Li B, Zhang RX, Sui CJ, Yin ZF, Yang JM. Clinicopathological significance of ZEB1 protein in patients with hepatocellular carcinoma. Ann Surg Oncol 2012;19:1700-6.

113. Nezos A, Pissimisis N, Lembessis P, Sourla A, Dimopoulos P, Dimopoulos T, Tzelepis K, Koutsilieris M. Detection of circulating tumor cells in bladder cancer patients. Cancer Treat Rev 2009;35:272-9.

114. Msaouel P, Koutsilieris M. Diagnostic value of circulating tumor cell detection in bladder and urothelial cancer: systematic review and meta-analysis. BMC Cancer 2011;11:336.

115. Ju M, Kao GD, Steinmetz D, Chandrasekaran S, Keefe SM, Guzzo TJ, Christodouleas JP, Hahn SM, Dorsey JF. Application of a telomerase-based circulating tumour cell (CTC) assay in bladder cancer patients receiving postoperstive radiation therapy: a case study. Cancer Biol Ther 2014;15:683-7.

116. Häfner N, Gajda M, Altgassen C, Hertel H, Greinke C, Hillemanns P, Schneider A, Dürst M. HPV16-E6 mRNA is superior to cytokeratin 19 mRNA as a molecular marker for the detection of disseminated tumour cells in sentinel lymph nodes of patients with cervical cancer by quantitative reverse-transcription PCR. Int J Cancer 2007;120:1842-6.

117. Sheng W, Ogunwobi OO, Chen T, Zhang J, George TJ, Liu C, Fan ZH. Capture, release and culture of circulating tumour cells from pancreatic cancer patients using an enhanced mixing chip. Lab Chip 2014;14:89-98.

118. de Albuquerque A, Kubisch I, Breier G, Stamminger G, Fersis N, Eichler A, Kaul S, Stölzel U. Multimarker gene analysis of circulating tumor cells in pancreatic cancer patients: a feasibility study. Oncology 2012;82:3-10.

119. Ankeny JS, Hou S, Lin M, OuYang H, Song M, Rochefort MM, Girgis MD, Isacoff WH, Wainberg ZA, Tseng HR, Tomlinson JS. Pancreatic circulating tumor cells as a diagnostic adjunct in pancreatic cancer. J Clin Oncol 2014;32:abstr175.

120. Kuhlmann JD, Wimberger P, Bankfalvi A, Keller T, Schöler S, Aktas B, Buderath P, Hauch S, Otterbach F, Kimmig R, Kasimir-Bauer S. ERCC1-positive circulating tumor cells in the blood of ovarian cancer patients as a predictive biomarker for platinum resistance. Clin Chem 2014;60:1282-9.

121. Obermayr E, Castillo-Tong DC, Pils D, Speiser P, Braicu I, Van Gorp T, Mahner S, Sehouli J, Vergote I, Zeillinger R. Molecular characterization of circulating tumor cells in patients with ovarian cancer improves their prognostic significance - a study of the OVCAD consortium. Gynecol Oncol 2013;128:15-21.

122. Kim JH, Chung HH, Jeong MS, Song MR, Kang KW, Kim JS. One-step detection of circulating tumor cells in ovarian cancer using enhanced fluorescent silica nanoparticles. Int $J$ Nanomedicine 2013;8:2247-57.

How to cite this article: Potdar PD, Lotey NK. Role of circulating tumor cells in future diagnosis and therapy of cancer. $\mathrm{J}$ Cancer Metastasis Treat 2015;1:44-56.

Received: 10-03-2015; Accepted: 28-05-2015. Source of Support: Nil, Conflict of Interest: None declared. 